DOI: $10.1515 /$ hssr -2017-0016

\title{
Idyll and Emotional Reality at the Dawn of French Romance
}

Brîndușa Grigoriu*

"Alexandru Ioan Cuza" University of Iasi, Romania

\begin{abstract}
In their attempt to provide a definition of the idyllic genre, readers of the medieval corpus of idyllic romance, from 1913 to our days, have discussed the relevance of such structural data as the lovers' age and similitude, their readiness to follow a bookish ars amandi or Nature's call, the patterns of mésalliance, the trials and tribulations of separation, and the notion of a happy end meant to change the face of the world. In order to integrate and synthesize these data, our study proposes a new approach to the idyllic corpus, based on the concept of "emotional reality" and its medieval counterparts.
\end{abstract}

Keywords

idyllic corpus, earliest French romances, emotional reality, medieval realism, possible worlds, structural necessity of faith.

The idea that a man can find the woman of his life at hand, in the very house of his parents, and grow up alongside her in sweet harmony, without ever leaving his "comfort zone", could make the modern reader smile. In the aristocratic "mesnie" of the Middle Ages as well as in our officially exogamic society, the possibilities of such a love scenario are smilingly limited, even in fictional works. Opposition and separation must occur, in

\footnotetext{
"Faculty of Letters, "Alexandru Ioan Cuza” University of Iași, 11, bd. Carol I, 700506, Iaşi, Romania; brindusagrigoriu@yahoo.fr
} 
order to disrupt the initial order and make room for... something like evolution.

In the so-called "idyllic romances" of the $12^{\text {th }}$ and $13^{\text {th }}$ centuries, when a girl and a boy are brought up together in a fraternal, symbiotic climate, and reach the age of their first love, they inevitably project an exalted view of themselves as the perfect match, a phantasmal realm which goes beyond or against "reality", following the appeal of amorous readings. Sooner or later, however, these wild dreamers (or readers!) are expected to acknowledge the facts and norms of their milieu and tune their expectations accordingly, a process that can lead to the emancipation of two valid humans out of the "puppy love" framework. Parents will disagree, children will question authority; a quest shall emerge, with promising findings.

In spite of the omnipresent threat of social incompatibility hovering on the medieval couple, the juvenile desire for a first, eternal love bond is, unlike in everyday life (Duby, 1996: 36; Baldwin, 1998: 258), systematically addressed and even quenched in these relative Utopias. Two possibilities occur at the narrative level: the couple may live happily ever after, or die happily and unite ever after. Thus, critics speak of "happy" or "unhappy" idylls, and discern two matters corresponding to these scenarios (Vincensini, 2009: 17 and Sobczyk, 2008: 99 sq).

In agreement with the etymological potential of eidos - a picture meant to inspire verdant aesthetic emotions ${ }^{1}$, but also a succession of emotional states rather than an epic series of events ${ }^{2}-$ the corpus to be explored in this paper is constituted of two upbeat ending stories where the ultimate conciliation of a young couple's intimate and public life illustrates medieval standards of happiness ${ }^{3}$. In order to find a promising, relevant angle for the approach of the first French idylls, a new criterion will be favoured: the notion of "emotional reality", seen as a world of experience "created rather than observed" (Sosny, 2008) in accordance with the cultural patterns shared in the "intersubjective situation[s]" (Agosta, 1984: 43-44) depicted in these narratives.

Of course, the present study must deploy its investigations cum grano salis, and avoid the dangers of a prejudiced reception: when speaking about "reality" in reference to the Middle Ages, it is not only the material world (res) that must be focussed on; a peculiar kind of "realism" infuses the philosophy of this age: 
Medieval realism is what we call idealism, if we are not thinking of idealism in a moral sense or in a special epistemological sense, but in terms of the ideas or essences of things which have reality and power of being. Medieval realism is almost the exact opposite of what we call realism today, and realism today is almost identical with what medieval people called nominalism. For medieval man the universals, the essences, the nature of things, the nature of truth, the nature of man, etc., are powers which determine what every individual thing, such as a tree, or every individual man will always become when he or she develops. This could be called mystical realism or idealism. Universalia realiathe universals are realities; this is medieval realism. (Tillich, 1972: 142)

To provide a sample of this kind of realism, relevant to the literature of the Central Middle Ages, one must mention that biographic facts are typically presented as illustrations of the so-called "Psychomachia", a battle between Virtues and Vices (see Snider, 1938), Love and Honour/Shame/Danger etc., in a world where allegorical figures creatively reinterpreted - prevail. In a nutshell, the medieval way of "psychologizing" often verges on personification, and unfolds agonistic patterns. Therefore, the modern construction of an emotional reality - where different drives fight for dominion or salience - is attuned to the medieval abstraction concerning the field of "realia", especially when laboured by the heroes of idyllic romances, who see Love, Nature and Fortune as a constant transcendence available to their apprehension.

The present investigation into the first idyllic plots of French literature endeavours to account for the enduring appeal of a youthful, idealistic ars amatoria in the narrative repertoire of medieval Europe. The luxuriant corpus of the Central and Late Middle Ages - which thrives thanks to the deep impact of its French models, from Floire et Blanchefleur to Floris et Lyriopé, via L'Escoufle, Galeran de Bretagne, Ipomédon, Guillaume de Palerne, Aucassin et Nicolette - can be contemplated in the light of a few theoretic notions particularly open to historical specificities: possible world matrices, ontology and epistemology of emotional realities.

\section{Idyll as a Matrix of Possible Worlds}

Since Myrrha Lot Borodine's study of 1913, the "idyllic programme" has been defined as a thematic nexus constituted of childish love, initiation 
and marriage, with a few variations in the $21^{\text {st }}$ century, when the "nuptial romance" was assigned a "genealogic political ideal" (Vuagnoux-Uhlig, 2009: 29) and a "transnational" dimension leading protagonists to build up bridges between civilisations (Galderisi, 2009: 35, note 18).

In order to account for this type of zoon politikon, idylls will be distinguished from other romances by an intriguing trait which deserves critical attention: the readiness of their tender protagonists to construct an alternative sphere of experience where one does not have to look very far to find the love of one's life, and invest it in an erudite, antique style, where brotherly familiarity can lead to lasting intimacy and social achievement, where no obstacle can overcome heartfelt affection, where pagans can marry Christians... only to undergo baptism, where lost children and lovers are found again, while Fortune cooperates with God: a counterfactual world which remains inaccessible to most of their elders. In the medieval romances impregnated with this form of sentimental policy, the generation gap is readily translated into a condition of success / failure in people's activity as architects of "possible worlds"4. Creative, resourceful youths are supported by experimented accomplices who, unlike the parents, choose to believe in the "printemps du coeur" (spring of the heart), and help the "aube de la vie sentimentale" (dawn of sentimental life) deploy the delicate inaugural promises which lie at the core of the idyllic genre (Lot-Borodine, 1913: 6). Team-work is a constant activity, but only under the oneiric leadership of neophytes. Binding affects must lead the way, and they always prove illuminating, thanks to the power of a love dream.

All in all, idyllic characters are able to recreate reality by following the universal raison d'être of their inner desires ${ }^{5}$, and by turning them into the macro-propositions of the plot. Thus, they reveal themselves by authoring an alternative course of events, always ready to sign their story with their own blood, in order to authenticate its realia.

If one were to draw a world matrix on the basis of relevant individuals and structuring proprieties, the scribal presence of two adolescents in love would unmistakably be the first necessary condition to fulfil so as to activate the idyllic programme ${ }^{6}$. Critics generally agree on the necessity of this essential trait, as well as on that of a social obstacle (the spectre of mésalliance!) and of a few empathetic allies representing the public. Thanks 
to these narrative ingredients, a warm climate of solidarity and participative emulation can emerge at the horizon of the text.

To a "Lector in fabula", certain predicates of these loving, authoring adolescents are quite predictable. Thus, in accord with the horizon of expectations of this nascent genre, heroes must be ardent, faithful, sacrificially-tuned, but also clever, sophisticated persons, with apparently incompatible statuses, in spite of the numerous affinities they share, on account of their age ${ }^{7}$.

Of course, these predicates are vividly negotiated among medievalists. To give just one example of these bucolic debates, Myrrha Lot-Borodine's proposition of the essentiality of the lovers' innocence and chastity - âge d'or oblige (Lot-Borodine, 1913: 3) - is challenged nowadays, when the idyllic corpus is in expansion and covers four centuries of amorous, idealist, and voluptuous writings; in this new intertextual light, premarital abstinence appears to be an accidental attribute of the romance couple, who generally need the energetic motivation of a gratifying form of intimacy as a structuring line of force of their possible worlds. Such is the case in Floire and Blanchefleur, where the unmarried lovers spend delicious nights in the emir's tower; in L'Escoufle and in Guillaume de Palerne, where the heroes flee together, regardless of any conjugal (or societal) etiquette, or in Floris and Lyriopé, where a brotherly disguise favours the intercourse of the mythical protagonists - who prove to be humanly fecund. Examples may go on and on, for the Late Middle Ages, but these first samples of erotic emancipation should be more relevant in shaping the specificities of this narrative matter. To put it simply, the faith in love (Galderisi, 2009: 34) does not imply a Christian or feudal observance of virginity, the characters' paradisiacal innocence being over-evaluated, as most narratives diffuse a model of vague, passionately spiritual communion ${ }^{8}$, without any dogmatic overtones.

Beyond narrative variations, one nucleus gives trans-world consistency to the idyllic script: the kind of love privileged by these medieval romances is always a dyadic, symmetric relationship developing at the intragenerational level (at the same childlike age), but reaching society on a larger scale, through a rebelling, triumphant (e)motion of the spectrum of ambition. Idyllic lovers never content themselves with a minor or clandestine position. They must impose a valid model and achieve 
centrality - often, by acceding to the throne. However exemplary they become, their force is not a matter of perfectionism in a harmonious, loving form of communication, but rather of openness to a wide sequence of human affects. Thus, the dyad's metamorphic potential is moulded by the emotional relevance of feelings such as anxiety, desolation and mourning, suicidal desire, religious fervour, jealousy, trust, eagerness, satisfaction, sense of (inter)personal achievement, gratitude and pride, magnanimity - in a complex philtre whose beneficiaries are far from being hale and hearty. Actually, the stereotype of the amorous malady dominates the idyllic corpus as it does the world of courtly lyricism and romance; no specific remedy is proposed by these stories.

All in all, the matrix of these possible worlds must retain the presence of an exclusivist form of love, resting on mutual consensus; on a heartfelt antagonism toward their elders; on a sense of resilience and selfaccomplishment that can ripen in accord with the propagandistic / parodist goals of each romance.

The examples of Floire et Blanchefleur on the one hand, and of Aucassin et Nicolette, on the other, largely correspond to this matrix configuration where the otherworld urge can alter the initial social sphere, thanks to the normative efforts of the emerging generation. Astonishingly - for time travellers in search of a medieval Utopia - the characters of the purest forms of idyllic romance (Lot-Borodine, 1913: 268) gradually become dictator figures of new emotional regimes where violence is directed against non-conformism, as if the celebrated heroes have acquired an amnesic type of authority, transcending the actuality of love. As adults, they come to embody the severe, castrating instructors - and rulers - they used to defy: implicitly, the setting is ready for a paradigm shift in which charisma and oblivion can lead to dis-empathy, intolerance and tyranny, newly encouraged by such forms of social and religious tutoring as the romans de clergie (Foehr-Janssens, 1994: 65). From non-conformism to the obligation to conform, there is only a step to take, and the idyllic, springlike heroes are ready to take it.

\section{A Crude Emotional Reality: the Bloom of the First Idyll}

Robert d'Orbigny's Conte de Floire et Blanchefleur was a medieval success: preserved in four manuscripts, widely translated throughout Europe, it is 
generally considered as the prototype of the idyllic genre ${ }^{9}$, owing to its early cultivation of the romantic roots of Arab (Leclanche, 1980: 226-230) and Latin traditions (Romanova, 2005: 27) building on the power of juvenile, resourceful, enduring love. It is also one of the very first romances of French literature, as its date of redaction - around 1150 - makes it contemporary with the first antique text, the Romance of Thebes, a vernacular adaptation of Statius's Thebaid, where epic love leads to mass conversion ${ }^{10}$.

In the Prologue, the public is invited to learn about love ${ }^{11}$ from a crowned child and his valiant spouse, the future mother of Queen Bertheaux-Grands-Pieds (Bigfoot Berthe), herself the mother of the future Emperor Charlemagne (Charles the Great). Incrusted in this venerable matrix, the two protagonists are presented as young, creative individuals, ready to promote a new kind of affective and politic relevance, founded upon loving and defending one's right to love, marrying and reigning beyond religious or caste prescriptions, while imposing a different faith and a different model of faithfulness - to a traditionalist society.

No surprise is allowed, as the narrative project is disclosed from the very incipit (Leclanche, 2003: vv. 1-56, pp. 4-6) by a narrator whose knowledge derives from a woman's account of a monk's version of an unnamed, mysterious text. Whether this source exists or not, there is a moral lesson enclosed in this idyll, which has something to do with fate, faith and love:

Flores fu tos nés de paiiens / et Blanceflors de crestiiens. / Bautisier se fist en sa vie / Flores por Blanceflor s'amie, / car en un biau jor furent né / et en une nuit engenré. (Leclanche, 2003: vv. 17-22, p. 2) ${ }^{12}$.

Besides the spiritual texture woven by the prologue, leading to a pagan's rebirth through voluntary baptism, the Conte's project comprises other forms of rebirth in which a few specific modes of predication - reading pagan literature, playing chess, trading antiquities - contour some specialised sub-worlds, where the hero is redefined and the public sphere redesigned, according to pacific, creative values meant to invest various communication patterns. It is this flexibility powered by love that makes the conversion possible. All the roads lead to Rome... or Jerusalem, via Babylon. Eventually, Floire is the story of a romantic metamorphosis, but also a medieval guide to the emotional revolution from antique paganism 
to medieval Christianity, "to God's glory" (Leclanche, 2003: v. 3348, p. 174). The feast of "Pasque Flourie" (Palm Sunday) is a way of saluting this era of amendment, where anonymous enthusiasts become teachers and preachers, where everybody and everything - even stones - can voice the hope of a new era.

However genuine, passionate, and empathetic it may appear, Floire's choice of the Catholic Church, in itself, is far from representing his - and even less Blanchefleur's - aspiration to a better world, more liberal and more liberating: the lovers' utopia, as announced in the prologue, becomes a real dystopia for their opponents, and prepares an epilogue where the antagonism of war and love (geste versus roman ${ }^{13}$ ) loses its grip, as the caring spouses come to adopt the epic formula of religious genocide.

Thus, from the very first manifestation of the "idyllic" genre, the modern reader fails to embrace the vision of "a nonmilitary, nonadulterous, and nonhierarchical erotic relationship" 14 , that the Conte promotes by interlacing the topics of "amors" (v. 6) and "amor Diu" (v. 3322). Indeed, as Natasha Romanova puts it,

Idyllic romances find a way to integrate this love [amors] into society and exploit it to produce beneficial social change. Yet this integration is always achieved at a price, and a certain violence on the margins of the texts highlights the elements that remain unintegrated. ${ }^{15}$

Whatever the collateral damage, the Christian metamorphosis of Spain's entire population (v. 3333) must be met with wonder, gratitude and emulation. Thus, there is nothing scandalous to a medieval public in this display of violence that may unsettle modern readers:

Qui le baptesme refusoit / ne en Diu croire ne voloit / Flores les faisoit escorcier, / ardoir en fu u detrencier. (Leclanche, 2003: vv. 3329-3332, 174) ${ }^{16}$.

Indeed, the worldview favoured by lovers and validated by the storyteller centres on the ideal of an efficient, rhetorical and (predominantly) friendly conquest of the pagan territory: in a week or two, all the subjects be they rich or poor, noblemen or rogues - are duly christened (v. 3328). Such is the message that must have prevailed for the European audiences 
of the Central Middle Ages, who proved receptive to the appeal of this edifying story of amorous renovation ${ }^{17}$. Essentially, the story outline is supported by the prompt interventions of a partial and loving (!) God of lovers, whose task is to let live (the young rulers) and help die (the old time subjects), while turning the wheel of Fortune in the "right" sense: one that feeds fresh hearts on ancient blood.

After this gymnastics of "appropriation", the modern reader must be open to the acceptance of a "new way of being": as a murderous paramour (Ricœur 1981: 192). Indeed, one of the most striking predicates of Floire (and Blanchefleur) is theological efficiency, a trait which proves to be of the same structural necessity as the qualities of an authentic, optimist, winning lover. The possible world constructed by Floire's royal politics of caritas is mainly concerned with the topic of religious activism, as inspired by the Christian profile he sees in Blanchefleur, although the latter is rather unconvincing as a believer, and ready to commit suicide in trying circumstances $^{18}$. In the end, it is this fragile maiden who sparks and experiences the unswerving emotions of a martyrdom of love, at the emir's court. And it is her who supports, probably without suspecting her own powers, Floire's construction of a new emotional reality for his own people, by occasioning, through her (royal and wholehearted) presence these "immediate, unstable, personal events, which could have been otherwise" (Hatzimoysis, 2003: 157). In other words, the reader has the possibility of writing these ghost-chapters (Eco, 1985: 268-278) allowed by the text's openness to the couple's ever after... in order to saturate the horizon of expectations projected by the prologue.

A trifold narrative structure can therefore be grasped by any cogent, unbiased reader of Floire's idyll: besides the obvious interdependent bond of the symmetric couple, one must complete the lovers' world matrix with the connection Blanchefleur-God, and, last but not least, with the (sombre) tandem Floire-God. The three-dimensional construct thus obtained should be further developed through the problematic integration of the pagan deities intermittently invoked by the narrator, by Floire and his parents, alongside with the Christian God. As the final massacre proves, the incorporation of this old cultural ethos embodied by Felix, entitling a man to kill in the name of his crown (as is the case in the deadly attacks perpetrated by the king's troop over Christian populations, vv. 61-64, 70- 
$76,87-92)$, in a spirit compatible with the image of God the Almighty and of (other) golden idols, is achieved via the application of an august model of domination - which has proved its social efficiency at the very beginning of the romance, in spite of the Barbarians' tolerance of Christian female survivors - to a new, youthful, mystical context. Floire will also kill selectively: his sole victims are the mass representatives of "la gent vilaine" 19, while courtly barons are simply sermonized (blackmailed?) into Christianity, in a twofold - master / slave - public space.

To specify our analysis of the "emotional realities", old and new, that this first French "idyll" promotes, we can further distinguish, with Aaron Ben-Ze'ev (2000: 126-127), an "ontological" and an "epistemological" dimension of human sensitivity, allowing the reader to apprehend the narrative tradition of a "couple romance" (Otis-Cour 2005: 275-291) as illustrative of the dichotomy of "actual" and "projected" states of the world.

Thus, the predominant paradigm of love, as embraced by the protagonists, has the structuring virtue of engendering a concrete form of bodily resemblance, which bewilders all strangers during the adventurous journey of the story. The "ontological" sense of reality is actualised by the visual pattern of twinship which links the young lovers owing to this "air de famille" recognizable by third parties. One would even venture to speak of an avatar of the androgynous figure, torn asunder by life and wandering in search of the lost self... ${ }^{20}$, while considering the couple's separation and reunion patterns, but also the mysterious evidence of their endogenic-like relationship.

On the other hand, what catalyses this perception of a similitude between Floire and Blanchefleur is a certain kind of emotional expressivity: the pensive, sad, introverted mimic of a childish traveller who seems to be an otherworldly creature, obeying a mysterious code. Therefore, it is the protagonists' adherence to the same system of norms and values - roughly, the moral background of romantic fidelity - that allows the parallel between them to operate at the epistemological level as well. The would-be twins prove to be teammates in the architecture of a common dream, where symbiosis is a way of embracing the same possible world (and the same possibility of a world): an egalitarian reality for the sexes, and an optimistic phenomenology for the quest of original unity. 
However, when the dream comes true, the story must end, and elude the sight of the couple's potential divergence. The ever-after becomes a ghost-chapter, a guesstimate on the part of a more or less perceptive reader. Slowly but surely, the two children's maturation can and must lead to dissimilitude in both senses of the word: besides the loss of physical likeness (on the ontological level), the syntonic behaviour of the longing phase risks to be followed by the dramatically different emotions of the genocide script, causing them to undergo an inexorable role differentiation (on the epistemological level). If Floire must conform to the horizon of expectations of an authoritative reign following his father's, Blanchefleur may be shocked and disappointed at this "return of the repressed", and identify with the helpless victims rather than with the (helped and beloved!) torturer. The text allows for no "disjunction of probabilities" (Eco 1979: 142-144) on this delicate point.

However, if the accessibility of the lovers' world, as erected at the beginning of the story, was restricted to the dyad through an elitist usage of Latin, the situation changes dramatically at the end of the story, when everybody can make sense of the protagonists' impassionate speech - as martyrs - and of their implementation of Christendom - as martyr-makers. Henceforth, there no longer exists an Otherworld fit for lovers: Floire and Blanchefleur have adapted the world of objective experience to their own emotional reality - officially shared, since the charitable queen does not officially oppose the merciless king - and the result is a new public setting, leaving no room for intimate communion...

On the whole, and despite the evidence of the public stage, the initial breach of the parental instance represented in the text - opposing a supportive, sensitive mother to an austere father ${ }^{21}$ - implicitly leads to a closing pattern of sexual differentiation as well. Man and woman cannot stick forever to the picturesque oneness of a symbiotic childhood. Floire rejoices in his military and theological success, whereas Blanchefleur enjoys her royalty and her mother's marriage to a duke. Floire embraces God and the Virgin - as political banners - whereas Blanchefleur and her surviving blood relation benefit from Fortune's caprice, witnessing the apocalypse of a world of desperados which resembles their own initial condition as escapists. It is the Providence of the story that insinuates this subliminal divergence at the core of the couple's apotheosis. The inevitable process of 
role differentiation is complete when each of the lovers can build his / her own possible world, which becomes ever less accessible to the other. At one pole of experience, one can contemplate a motherly realm where Christian slavery is transcended by the blossoming, loving conception of King Charlemagne's mother, at the other, a filicidal dominion where a pagan sovereign becomes the exterminator of his own subjects, after having embraced Latin literature, chess proficiency and a catholic credo. The violence of a well-bread lad fits the model of a crusader, and the head of a romance paramour remains brilliantly crowned.

Ultimately, this first French idyll nurtures the political demagogy of love, viewed as caritas and as pitie de norreture ${ }^{22}$, despite the pitiless charity of the Spanish conversion. It is a state emergency to send unrepentant pagans to hell, and to retain all adepts of Christianity. The stunning blossom of Floire and Blanchefleur has the fragrance of happy murder and successful assimilation, while cultivating the sprout of happy marriage.

\section{An Infernal Idyll: the Possible Worlds of a Chantefable}

The anonymous "chantefable" Aucassin et Nicolette - preserved in a single manuscript - would be a generic hapax, if medievalists had not succeeded in presenting it as a subtle, subversive and probably censored idyll ${ }^{23}$. Its parodist tinges cannot prevent an impartial researcher from taking it seriously, as a constructivist attempt at providing a guide to amorous bliss and social success; the tandem of a manly maiden and a girlish young man is humorously efficient in elaborating "new ways of being in the world" (Ricœur 1981: 56). In their quality of trouveres of their own story, the "deus biax enfans petis" (two small beautiful children; see Dufournet, 1984: v. 3, p. 42) play on such emotional cords as love, rebellion, sacrificial availability, suicidal fits and farcical jubilation. In the wake of Floire and Blanchefleur, Tristan and Ysolt, Ismene and Atys, Antigone and Partonopeus, and of other romance couples adhering to a romantic epistemological reality, they actively build an alternative universe where love is a matter of election, and not of moral or political prescription. Thus, a baptised pagan slave can become the lawful wife of a Christian count's son, and Hell may appear as the best possible world... to a lad who believes man to be a better lover than woman, in the event of separation, and a better killer, in the event of war. 
From the very beginning, amity and sentimental immutability are observed in an obstinate, childish way: once again, there is a comfort zone - a locus amoenus of peace and harmony, of symbiotic bliss and synchronic evolution - to defend against the adults' intrusion.

As it is often the case in the narrative corpus of the Central Middle Ages, war can oppose love, but without making it irrelevant: confronted to the mission of defending his fatherland from assailants, Aucassin invokes God's power to support his own private cause, and goes as far as to suggest to his perplexed father the possibility to embrace a love marriage between himself and the beautiful slave who has become his intimate friend:

Ja Dix ne me doinst rien que je li demant, quant ere cevaliers, ne monte el ceval, ne voise en estor, la u je fiere cevalier ne autres mi, se vos ne me donés Nicolete ma douce amie que je tant aim. (Dufournet, 1984: 21-25, p. 64) ${ }^{24}$.

The modern reader may be surprised to visualize, through the eyes of a lover, the pater as the owner of this reified "douce amie". It seems that the ex-slave is still regarded as the count's property, and, therefore, as a possible trophy for the young master, if he should prove to be an efficient defender of the county.

When the passionate lad understands that (a) Nicolette is too much to ask for, he shrewdly reformulates his love petition and demands a simple, punctual reward in order to play his (filial) part: the permission to exchange a few kisses and words with her. The comic overtones of the scene play on the dilemma of what a good educator should encourage in his son: the right to love and honour an outsider or the right to strike and terminate one's enemies -options which appear to be curiously interrelated. Even if the count of Beaucaire does accept the "lesser evil" of a light contact, while vigorously refusing the alternative of a mésalliance (Dufournet, 1984: 2628 , p. 64), the obstacle he stands for is proclaimed insurmountable - "ce ne puet estre." 25 - viewed in the light of social and political necessity.

This sense of outer immutability - reminiscent of a belief in Fate - can and has to be shattered by that of the young hearts bound together in a different form of need. Indeed, however sound the arguments of the grown-ups, however stable the set of norms and standards they set for the 
emotional life of the juvenes, no consolation prize is accepted: as in Robert d'Orbigny's story, the tender lovers cannot be reasoned into adulthood and they cling to the possibility of a life/death setting where affectionate togetherness is allowed, beyond any laws of social compatibility. Once again, familial familiarity is experienced as a natural foundation of intimacy, and Aucassin - whose name is reminiscent of the profile of a goose ${ }^{26}-$ refuses to leave the only paradise he knows: that of pleasurable cohabitation, fraternal consubstantiality and erotic bliss. He explicitly faces his mother's threat and justifies his attachment in affective, social and mystic terms:

Mere, je n'en puis el faire: / Nicolete est de bon aire; / ses gens cors et son viaire, / sa biautés le cuer m'esclaire. / Bien est drois que s'amor aie, / que trop est douc. (Dufournet, 1984: 13-18, p. 48) ${ }^{27}$.

If this sweet paradise of courtly cohabitation is lost, it is through the parents' ominous intervention, especially as a consequence of the death sentence established not only for the involuntary intruder (the ex-slave), but also for her noble godfather (the Christian viscount of Beaucaire), in case the liaison is further encouraged.

Persecuted and imprisoned for her social and political otherness, and for the insolence of accepting Aucassin's love, Nicolette must jump into the unknown, one night, and be initiated into pain and mortality, as she prefers the scenario of an intimate, seemingly accidental death to the script of a public execution - while counting on God's help and support:

Hé! Dix, fait ele, douce Creature! Se je me lais caïr, je briserai le col, et se je remain ci, on me prendera demain si m'arde on en un fu. Encore ainme je mix que je muire ci que tos $l i$ pules me regardast demain a merveilles. (Dufournet, 1984: 12-16, p. 90) ${ }^{28}$.

The Creator that Nicolette addresses is a sweet Creature (!) of her sweet, amicable nature, who must bless the project of love martyrdom or love escape. Happily for the idyllic horizon of expectations, the beautiful trobairitz - as an architect of God's world - will be spared and given the opportunity to imagine growingly complex scripts of amor de lonh. Even when the long-awaited reunion of the couple becomes imminent, the 
resourceful "fee" (Dufournet, 1984: 30, p. 98) keeps her beloved at a distance, and plays on his desire, only to make him evolve, spiritually, and "deserve" her full favours.

Furthermore, this evolution implies Aucassin's acceptance of Nicolette's otherness, as a woman and as a Carthaginian princess, under the disguise of a black jongleur. In this Tristanian scene, two possible worlds are created: one where a male narrator replaces the heroine, only to talk about her unequalled qualities, and one where a noble woman of pagan descent wants to marry her Christian lover and be assimilated in his cultural paradigm - although she has the choice of a royal marriage to a Saracen. A form of inner racism and self-denial seems to motivate her use of the "esclaire" - a herb meant to restore her whiteness and turn her into the bride of a future white ruler:

Having been raised in Biaucaire, Nicolette is the product of a society that is structured around a set of values that allocates a specific place to women and regards Saracens (Arabs) as despised pagans ('paiien felon'). Nicolette wants to escape her identity and her place within the symbolic order. In order to achieve this and enter into the imaginary, she needs Aucassin to do the work for her - not to recognize her in the black male jongleur garb but to accept her as a white princess so that the two of them can live happily ever after. (Romanova, 2005: 188)

The idea of a complementary, not-so-dissimilar pair receives an epistemological rather than an ontological illustration: no peculiar resemblance between the protagonists is asserted, except for this whiteness which is the privilege of any castellan's life; the emotional communication only rests on a sense of openness to the other and on a form of brotherly connectedness in spite of distance. From an epistemological point of view, both of them support and invest the relevance of a heavenly Father, when they feel hopeless and come to share the condition of orphan children:

[Nicolette:] se clama orphenine [...]: Por vos sui en prison misse [...] mais, par Diu le fil Marie, / longement n’i serai mie, / se jel puis far[e]. (Dufournet, 1984: 14, 20, 23-25, p. 54$)^{29}$.

[Aucassin:] Se Diex plaist le pere fort, je vous reverrai encor, / suer, douce amie. (Dufournet, 1984: 16-18, p. 112) 
Whether they think of God the Father or of Jesus and his Mother, both lovers project a world structure resting on certain family ties to a Christian, Trinitarian transcendence. As for God's pertinence to the structural nexus of this tickling love story, it is less evident that faith can support faithfulness. Nicolette uses her "saint" body to heal another man's wounds, while her pilgrim of the heart errs in quest of his own (affective and corporeal) health. At times, Aucassin becomes Tristan's bitterest avatar, and cultivates a misogynist kind of jealousy and scepticism (Dufournet, 1984: 3-15 and 19-25, pp. 84 and 86) that Nicolette alone can confront and overcome. In order to test her man's love - and compare it to her own version - she appeals to a ludic kind of God... who must unmistakably guide a true lover to the flower hut of his beloved, or else be dismissed:

[Nicolette] jure Diu qui ne menti, / se par la vient Aucasins / et il por l'amor de li / ne s'i repose un petit, / ja ne sera ses amis, / n'ele s'amie. (Dufournet, 1984: 17-22, p.100) ${ }^{31}$

The leaves, flowers and herbs of the hut must be interpreted as a oneguess, unique signature, as if Nicolette were a kind of Venus leading the way, presenting her golden apple and inviting to the revelations of Amor, while praying the Holy Trinity... just to make sure she puts all the odds on her side. It is this optimistic, eclectic, step-by-step construction of a common world, astutely managed by Nicolette, that makes the story go on.

At each particular moment of her escapade, a reversed hunt is launched, de par Diu (for God's sake): the "ciere beste" (precious beast) knows she will be missed and followed (see Dufournet, 1984: 26 and 39, p. 98); thus, she prints down her message in whatever format she can find, from the verdant wilderness to the marvels of human civilization. Aucassin must play the reader's / hunter's role, and decipher the most challenging codes. With every prowess of interpretation, he proves to be the perfect match for her, or the perfect recipient of a possible world where she sets the tone or the semiotic wave - and he simply has to track it.

To complicate matters, or to respond to the existing complexities of the idyllic horizon of expectations, Aucassin needs to face the world upside down of Torelore in order to become fit for the role of dictator ascribed to a successful romance lover of the Central Middle Ages. Thus, he learns to 
impose his emotional reality to this realm where men behave as if they were inferior to women, and perfectly replaceable at war. Additionally, he preaches - in facts and in words - the would-be necessity to kill one's enemies, instead of hitting them with harmless fruits and eggs. As he embraces this patriarchal, clerical, misogynist perspective by displaying the murderous power of his sword, the hero disqualifies the narrative's attempt to build a Utopian universe where women are the best of leaders and men can effusively rely on them. Torelore is, however, a paradise on earth, where lovers can live together for three years of voluptuous oblivion, in spite of their questionable kind of complementarity and authority (Dufournet, 1984: 9-20, p. 138). When the Saracens besiege the land, Aucassin is unable to defend himself and his lover, in spite of all his previous demonstrations of potency. He has no choice but to return home, and rule his orphan land far from Nicolette, who is forced by the most improbable of hazards to discover her own native town of Cartagena. As a princess lost and found, she can choose a royal spouse of her country, whereas the new ruler of Beaucaire swears on his "Diu de maïsté" (God of majesty) that he misses his sweetheart more than his dead parents and will do anything it takes to find her again (Dufournet, 1984: 5-15, p. 144). Nobody wants to force an advantageous marriage on him now; the only obstacle Nicolette has to face is Aucassin's own blindness. Accordingly, a spiritual God is summoned to her help:

Ce doinst Diu l'esperitables / c'oncor vos tiengne en me brace, / et que vos baissiés me face / et me bouce et mon visage, / damoisiax sire (Dufournet, 1984: 14-18, p. 148) ${ }^{32}$.

In spite of these prayers which devise a world of divine majesty and spirituality, the happy end - equally desired by the white Saracen princess and the white( $\mathrm{r}$ ) governor of Beaucaire, in their different sacrificial projections - is by no means a bloody flood of conversions, since the (inevitable!) baptism scene has been peacefully achieved at the very beginning of the story. The two Christians are more interested in their own "joie (joy)" than in the advent of a better, more faithful world.

Floire and Blanchefleur's ideals are, however, unambiguously shared by these romance lovers who follow close in their footsteps, only a few decades away: the belief in constancy, the obstinate determination to 
choose one's companion for life - even if this choice uproots one's sense of cultural belonging - the lyrical and theological intonations which mark out the couple's emotional reality, the power to love and kill, while becoming a model for lovers - and killers... in the end, virile values are reasserted, while the feminine sweetness of the longing stage is incorporated in an idealistic propaganda just as cruelly discriminatory as the initial class racism. Ontologically speaking, a generation replaces and displaces the other, while the consensual principle ${ }^{33}$ triumphs in the couple. However, the right to say yes to one's heart is only granted to noble lovers. At the epistemological level, the reader is invited to contemplate the political alliance of two majestic rulers, while Beaucaire becomes a land of conjugal delight, patriarchal values and amorous gratification.

All in all, the first and most celebrated idyllic romances of the French Middle Ages prove to be counterfactual invitations to find a transcendent dimension at the couple's image and resemblance, one of spiritual efficiency, love and faith, allowing the lovers to become the acclaimed (or excruciating) architects of a new emotional reality, where children must be obeyed and their vision unmistakably shared, however irrational it may seem. Floire's Spanish dictatorship of caritas, Aucassin's bloody lessons of manhood in Torelore reveal a challenging ars amandi, in which the charismatic, liberating heroes end up imprisoning their vassals or inferiors in a new network of interdictions, as if any happy ending story had to reenact the eternal script of oppression and martyrdom, while choosing to see the silver linen instead of the ominous clouds of the past.

All in all, the Conte and the Chantefable set an ideal of dyadic communication and dominion, of intellectual and affective meritocracy instituted by the young, as if the field of romance were the fertile land for the biblical seeds of pure-hearted, clairvoyant infancy: "Let the little children come to me, and do not hinder them, for the kingdom of heaven belongs to such as these." (Mathew, 19: 14). ...The kingdom of earth too, especially in the otherworld of fiction, where "God loves lovers" (Dufournet, 1984: 12, p. 124)... Playfulness, spontaneity, even cruelty, can thus become exemplary values in an emotional reality suited for the weak greatly empowered, lovingly gifted, arbitrarily crowned rulers of their people. The initial trauma of a persecuted self can thus find a way to accede 
to the institutional paradigm of a newly traumatic regime, whose legitimacy rests on the rightfulness (and rawness) of Nature - youthfully acculturated.

\section{References}

Aucassin et Nicolette, ed. Jean Dufournet. Paris: Flammarion, 1984.

Baldwin, J. W. (1998 [1993]) "Consent and the Marital Debt: Five Discourses in Northern France around 1200". Consent and Coercion to Sex and Marriage in Ancient and Medieval Societies, ed. Angeliki E. L. Washington D.C.: Dumbarton Oaks,. 257-270.

Ben-Ze'ev, A. (2000). "When Feelings Overflow", chapter 5. The Subtlety of Emotions. Cambridge, Massachusetts and London, England: Massachusetts Institute of Technology. 117-160.

Boquet, D. (2005). L'Ordre de l'affect au Moyen Âge. Autour de l'anthropologie affective d'Aelred de Rievaulx, Caen: Publications du CRAHM.

Buschinger, D (ed) (1990). L'Idée de bonheur au Moyen Âge. Actes du colloque d'Amiens de mars 1984, Göppingen: Kümmerle.

Calin, W. (1989). "Amadas et Ydoine: The Problematic World of an Idyllic Romance". Continuations: Essays on Medieval French Literature and Language In Honor of John L. Grisby, eds. Norris J. Lacy, Gloria Torrini-Roblin. Birmingham, Alabama: Summa Publications. 39-49.

Duby, G. (1996 [1988].) Love and Marriage in the Middle Ages, transl. Jane Dunnett. Chicago: University of Chicago Press.

Eco, U. (1985 [1979]). Lector in fabula. Le rôle du lecteur., transl. Myriem Bouzaher. Paris: Grasset \& Fasquelle.

Faaborg, Jens N. (1997) Les Enfants dans la littérature française du moyen âge. Copenhagen: Museum Tusculanum Press.

Galderisi, C. (2009). "Idylle versus fin'amor? De l'amor de lonh au mariage". Le Récit idyllique. Aux sources du roman moderne, eds. Jean-Jacques Vincensini, Claudio Galderisi. Paris: Classiques Garnier. 29-44.

Gaunt, S. (1995). Gender and Genre in Medieval French Literature. Cambridge: Cambridge University Press.

Hatzimoysis, A. (ed) (2003). Philosophy and the Emotions,. Cambridge and New York: Cambridge University Press.

Kay, Sarah. The 'Chansons de geste' in the Age of Romance. Oxford: Clarendon Press, 1995.

Leclanche, J.-L. (1980). Contribution à l'étude de la transmission des plus anciennes cuvres romanesques françaises: Floire et Blanchefleur, vol. II. Lille: Service de reproduction des thèses de Lille-III. 
Lot-Borodine, M. (1913). Le Roman idyllique an Moyen Âge. Paris: Auguste Picard Éditeur.

Moore, M. (2007). "Boundaries and Byzantines in the Old French Floire et Blancheflor". Dalhousie French Studies 79. 3-20.

Otis-Cour, L. (2005). "Mariage d'amour, charité et société dans les 'romans de couple médiévaux" ". Le Moyen Age 2 CXI. 275-291.

Raynaud de Lage, G. (1976). Les Premiers romans français et autres études littéraires et linguistiques, Geneva: Librairie Droz.

Ricœur, P. (1981). Hermenentics and the Social Sciences. Essays on Language, Action and Interpretation, ed. and transl. by John B. Thomson. Cambridge / Paris: Cambridge University Press / Maison des Sciences de l'Homme.

Robert d'Orbigny. (2003). Le Conte de Floire et Blanchefleur, ed. and transl. JeanLuc Leclanche. Paris: Champion.

Romanova, N. (2005). Medieval French Idyllic Romance (12th and 13th Centuries): A New Look. London: University College.

Sobczyk, A. (2008). L'érotisme des adolescents dans la littérature française du Moyen Age. Louvain: Peeters.

Sosny, S. (2008). "What Is Your Emotional Reality?”. Psychology Today available online

at https://www.psychologytoday.com/, consulted on the $26^{\text {th }}$ of April 2017.

The Psychomachia of Prudentius. Master's thesis, ed. Louis B. Snider. Chicago: Loyola Press, 1938.

Tillich, P. (1972). A History of Christian Thought, from Its Judaic and Hellenistic Origins to Existentialism, ed. Carl E. Braaten. New York: Harper \& Row, Touchstone.

Vincensini, J.-J. (2009). “Introduction”. Le Récit idyllique..... 7-26.

Vuagnoux-Uhlig, M. (2009). Le couple en berbe: "Galeran de Bretagne" et "L'Escoufle" à la lumière du roman idyllique médiéval. Geneva: Droz.

\footnotetext{
${ }^{1}$ The idyll derives from the Latin noun idyllium, from the Greek noun eidyllion "short, descriptive poem, usually of rustic or pastoral type," literally "a little picture," diminutive of eidos "form". See The Online Etymology Dictionary, available online at http://www.dictionary.com/.

${ }^{2}$ Pour Myrrha Lot-Borodine, l'idylle “n'est qu'un tableau, ou, si l'on aime mieux, une série de tableaux intimes; c'est un état d'âme bien plus qu'une geste. »; see EAD 1913: 269-270.

${ }^{3}$ To contemplate some relevant angles on the medieval idea of happiness, see Buschinger 1990.
} 
${ }^{4}$ On the relevance of the concept of "possible worlds" for the interpretation of narratives, see Eco 1985: chapter 8, "Structures de mondes. Est-il possible de parler de mondes possibles ?" : 157 sqq.

${ }^{5}$ Desires can be considered as "propositional attitudes" - I desire that events take this particular course - catalysing narrative transformations. See Eco 1985: 165.

6 "In idyllic romance, love is the centre of the universe, the unique motivating force behind the action.", Calin 1989: 40.

7 On the lovers' model of "entente générationnelle" leading to the blossoming of ethical, revolutionary values, see Galderisi 2009: 36-37: "Leur union semble se fonder sur un rituel de reconnaissance et d'exclusion des autres, sur une surdétermination du rapport horizontal et paritaire par rapport au rapport vertical et autoritaire".

${ }^{8}$ On the protagonists' intimacy and the fact that their sexual involvement is never explicitly confirmed, see Faaborg 1997: 281-282.

${ }^{9}$ See Vincensini 2009: 10.

${ }^{10}$ See Raynaud de Lage 1976: 153.

${ }^{11}$ Robert d'Orbigny, Le Conte de Floire et Blanchefleur, ed. and transl. by Jean-Luc Leclanche 2003 : v. 5, p. 2.

12 "Floires was born to a pagan, Blanchefleur to a Christian family. For the sake of Blanchefleur, his sweetheart, Floire demanded to be baptised: they had been born on the same day and engendered on the same night." Translation is mine, unless otherwise indicated.

${ }^{13}$ On the relevance of female characters and love plots in the medieval genre of romance, see Gaunt 1995: 71-75. For a systematic opposition of the narrative matters of the chanson de geste and the romance, see Kay 1995.

${ }^{14}$ Calin $1989: 39$.

${ }^{15}$ I would like to express my full gratitude to the author for offering me full access to her remarkable, yet unpublished thesis: Romanova 2005. The present quotation refers to p. 18 of her dissertation.

16 "Whoever refused baptism or faith in God was flayed or burned or quartered at Floire's orders". On the strategic implications of a crusade-like propaganda in Floire and Blanchefleur, see Moore 2007: 14-15.

${ }^{17}$ On the diffusion of the aristocratic version of Floire and Blanchefleur, see Leclanche: VII and XXIV. The author mentions that four manuscripts in French are preserved, and the story is translated into Norse, Swedish, Danish, then English, Flemish, German, and especially in Italian (Cantare di Fiorio y Biancifiore), while further adaptations are made in Spanish, Greek, etc., only to return to French via Boccaccio (Il Filocopo).

${ }^{18}$ See vv. 2407-2408, p. 124. 
19 "Plebeian people": v. 3327, p. 174.

${ }^{20}$ On the limits of this Platonic view in the Middle Ages, and on Aelred's affinities with an androgynous perspective on the human couple in Paradise, see Boquet 2005: 286.

${ }^{21}$ See Vuagnoux-Uhlig 2009: 29.

${ }^{22}$ The phrase is used by Chrétien de Troyes, in Erec et Enide, v. 1438-47, in the second half of the $12^{\text {th }}$ century.

${ }^{23}$ See Jean-Charles Payen: Aucassin «offusque le confort intellectuel du public médiéval [et] bouscule trop de poncifs, même si la provocation s'y dissimule sous un dehors bon enfant », quoted by Dufournet 1984: 9 .

24 "May God never grant me what I ask of Him, when I become a knight, mount a horse and fight against other knights, if you do not grant me the right to marry Nicolette, my sweet friend that I love so".

25 "That cannot be".

${ }^{26}$ From "aucassa", the diminutive of the Provençal "auca", meaning "goose". See Dufournet 1984: 10.

27 "Mother, I cannot do otherwise. Nicolette is of noble origin; her charming body and her face, her whole beauty illuminate my heart. It is right that I love her, for she is too sweet (to resist)". One must remark that the phrase "avoir s'amor" can also translate as "to have her love", in spite of the context of irresistible feminine charisma.

28 "Oh, my Lord, says she, sweet Being! If I let myself fall, I will break my neck, but if I stay, they will capture me tomorrow and burn me at stake. I had rather die right here than be executed tomorrow, in front of a whole people watching me curiously".

29 "Nicolette claimed herself an orphan [...]: It is on account of you that I am imprisoned [...] but, by God, Mary's son, I won't be here long, if I can do anything about it."

30 "If it should please God the mighty father, I'll see you again, my sister, my sweetheart."

31 "[Nicolette] swears by God who never lied that if Aucassin should pass thereabouts and refrain from lingering a little for the love of her, he would nevermore be her beloved, nor would she be his lover."

32 "May the Holy Spirit let me hold you in my arms again, so that you kiss my face, my mouth, and my cheeks, my young sire."

${ }^{33}$ See Otis-Cour 2005: 275-291. 


\section{Biographical note}

Brînduşa Grigoriu is an Assistant Professor at the "Alexandru Ioan Cuza" University of Iași. After her Ph.D. dissertation on the Romance of Tristan, she explored other genres of medieval French literature in her study Talent / maltalent. Émotionologies liminaires de la littérature française, Craiova, Universitaria, 2012, in her coedition of Le Lai du Conseil, University of Liverpool, Liverpool Online Series, 2013, and in her essay Actes d'émotion, pactes d'initiation: le spectre des fabliaux, Craiova, Universitaria, 2015. She is now preparing a book on the idyllic romance corpus of the $12^{\text {th }}-15^{\text {th }}$ centuries. 